\title{
Nitrate Nutrition and Temperature Effects on Wheat: Enzyme Composition, Nitrate and Total Amino Acid Content of Leaves
}

\author{
D. W. LAWLOR ${ }^{1}$, F. A. BOYLE ${ }^{2}$, A. C. KENDALL ${ }^{2}$ AND A. J. KEYS \\ ${ }^{1}$ Physiology and Environmental Physics Department, Rothamsted Experimental Station, \\ Harpenden, Herts. AL5 2JQ, U.K. \\ ${ }^{2}$ Biochemistry Department, Rothamsted Experimental Station, Harpenden, Herts. \\ AL5 2JQ, U.K.
}

Received 20 October 1986

\begin{abstract}
Lawlor, D. W., Boyle, F. A., Kendall, A. C. and Keys, A. J. 1987. Nitrate nutrition and temperature effects on wheat: Enzyme composition, nitrate and total amino acid content of leaves. $-\mathbf{J}$. exp. Bot. 38: $378-392$.

Wheat plants were grown in controlled environments in two temperature regimes with two rates of nitrate fertilization. In some experiments two light intensities were combined with the nitrogen and temperature treatments. The composition of the third leaf was studied from soon after emergence until early senescence. The amounts of chlorophyll, soluble protein, ribulose bisphosphate carboxylase-oxygenase (RuBPc-o) protein, nitrate, and total amino acids were measured together with the activities of RuBPc-o, fructose-1,6-bisphosphatase, glycolate oxidase, carbonic anhydrase, nitrate reductase, glutamine synthetase and serine- and glutamate-glyoxylate aminotransferases. Additional nitrate supply increased the amounts, per unit leaf area, of chlorophyll, total soluble protein and RuBPc-o protein and the activities of all the enzymes. The ratio of RuBP carboxylase to RuBP oxygenase activity, when measured at constant $\mathrm{CO}_{2} / \mathrm{O}_{2}$ ratio and temperature, was unaffected by growth conditions or leaf age. Leaves grown at the lower temperature, especially with more nitrate, contained much more soluble protein, nitrate reductase, fructose bisphosphatase and free amino acids per unit area than the plants grown in the warmer conditions. However, young leaves grown in the warm contained more nitrate than those grown in the cool. Amounts of protein, amino acids and chlorophyll and most enzyme activities reached maxima near full leaf expansion and decreased with age; additional nitrate slowed the decrease and senescence was delayed. Nitrate content and nitrate reductase activities were highest in leaves before full expansion and then fell rapidly after full expansion. Increased light intensity increased the content of RuBPc-o protein at the higher rate of nitrate supply. Chloroplast components and, to a lesser extent, peroxisomal enzymes associated with photosynthetic nitrogen assimilation changed in proportion with different treatments but nitrate reductase activity was not closely related to chloroplast enzymes. Control of tissue composition in relation to environmental conditions is discussed.
\end{abstract}

Key words -Nitrate nutrition, temperature, wheat, enzyme, amino acid, leaves, ribulose bisphosphate carboxylase oxygenase, nitrate reductase.

Correspondence to: Physiology and Environmental Physics Department, Rothamsted Experimental Station, Harpenden, Herts. ALS $2 J Q, U . K$.

\section{INTRODUCTION}

Nitrogen fertilization of crops (particularly with nitrate fertilizers) is the main means of manipulating plant growth for agricultural purposes. By applying nitrogen in the correct form and amount, and at times related to the demands of growth, plant characteristics may 
be modified to optimize production with economic use of fertilizer. The molecular mechanisms of nitrate and carbon dioxide assimilation are understood in some detail, but the coupling of biochemical processes to produce the physiological events and whole plant responses are only semi-quantitatively understood (Hageman, 1979). Nitrate increases the size and longevity of leaves and the content of proteins, pigments etc. The rate of photosynthesis per unit area may also increase but is often observed to have a limited response to nitrate; dry matter production by crops reaches a plateau at high nitrate application and correlation between crop production and photosynthetic rate is often poor (Hesketh, Ogren, Hageman, and Peters, 1981).

Temperature also affects the growth and production of crops; decreasing photosynthetic efficiency as temperature rises is related to greater ribulose bisphosphate (RuBP) oxygenase activity and the accompanying photorespiration. In warm conditions and with abundant nitrogen, photorespiration of field grown winter wheat (Thomas, 1976, 1977) increased as a proportion of net photosynthesis. Balance between the photosynthetic and photorespiratory carbon and nitrogen cycles is temperature-dependent and photorespiration increases more than $\mathrm{CO}_{2}$ assimilation at higher temperatures (Keys, Sampaio, Cornelius, and Bird, 1977). It is not known if the balance between photosynthesis and photorespiration (Keys, Bird, Cornelius, Lea, Wallsgrove, and Miflin, 1978) is altered by nitrogen supply or if nitrogen supply and temperature interact in determining it. The balance between the carbon and nitrogen cycles is possibly determined by the properties of RuBPc-o and conditions that prevail during development which regulate the amounts and activities of enzymes in the associated metabolic pathways. Whilst the effects of temperature can be understood in terms of the properties of RuBPc-o in vitro, it is not clear why or how nitrogen nutrition affects the balance of oxygenation and caarboxylation, or alters the capacity of associated metabolic processes.

The objective of the work described here was to analyse the effects of nitrate fertilizer and temperature on the mechanisms of $\mathrm{CO}_{2}$ assimilation and nitrogen metabolism, in the intact plant, and to establish how changes in metabolism determine physiological processes culminating in plant growth. In this paper we examine how nitrate supply and temperature conditions during growth of leaves, and as they age, affect the amount of proteins and activities of some enzymes in wheat leaves and their nitrate and amino acid contents. RuBPc-o was studied as the key enzyme for both photosynthesis and photorespiration. Nitrate reductase was measured to indicate the capacity of leaves to assimilate nitrate. Other enzymes were chosen to indicate changes in the capacity of either carbon assimilation or photorespiration, and associated processes. In following papers the environmental conditions and changes in enzyme and plant composition are related to rates of photosynthesis and photorespiration (Lawlor, Boyle, Young, Keys, and Kendall, 1987a) and to soluble materials, carbon fluxes and to whole plant growth (Lawlor, Boyle, Young, Kendall, and Keys, in preparation).

\section{MATERIALS AND METHODS}

\section{Plant growth}

Plants of spring wheat (Triticum aestivum L. cv. Kolibri) were grown in controlled environments with a $16 \mathrm{~h}$ photoperiod under two temperature regimes, $23 / 18^{\circ} \mathrm{C}$ and $13 / 10^{\circ} \mathrm{C}$ (day/night). These treatments are referred to as warm (W) and cold $(\mathrm{C})$ in the text. The corresponding relative humidities were $74 / 88 \%$ (day/night) in the warm conditions and $55 / 76 \%$ in the cold conditions, giving a vapour pressure deficit of approximately $0.7 / 0.3 \mathrm{kPa}$. Quantum flux density during the day was $600 \mu$ mol quanta $\mathrm{m}^{-2} \mathrm{~s}^{-1}$. In one experiment, plants were grown at 350 and $600 \mu$ mol quanta $\mathrm{m}^{-2} \mathrm{~s}^{-1}$ under the two temperature regimes. Illumination was from a mixture of fluorescent (total $15 \mathrm{~kW}$ ) and tungsten lamps (total $2 \cdot 4 \mathrm{~kW}$ ). 
Fifteen seeds were sown in a mixture of sand and peat in each $15 \mathrm{~cm}$ plastic pot, and thinned to 10 plants at emergence of the first leaf. At sowing, pots were watered with $100 \mathrm{~cm}^{3}$ of Hoagland's solution to give $0.9 \mathrm{mmol} \mathrm{NO}_{3}^{-}$per pot. Twice each week for 4 weeks therafter one group of pots was given 0.45 mmol of nitrate per pot in Hoagland's nutrient. The other group was given Hoagland's solution supplemented with sodium nitrate to give $3.9 \mathrm{mmol}$ of nitrate on sowing and twice weekly applications each of $2.0 \mathrm{mmol}$. These nitrate treatments are referred to as the low $(-\mathrm{N})$ and high $(+\mathrm{N})$ nitrogen treatments. All other nutrients were constant between treatments, except that $\mathrm{NaCl}$ was substituted for $\mathrm{NaNO}_{3}$ in the $-\mathrm{N}$ treatment to maintain ionic balance between $-\mathrm{N}$ and $+\mathrm{N}$ treatments. Pots were watered twice daily. Trolleys holding the pots were rotated in the controlled environment rooms twice weekly to compensate for any variation in conditions within the chambers.

Leaves were sampled $13,15,17,21$ and $24 \mathrm{~d}$ after sowing in the warm conditions and after 22, 26, 29,36 and $42 \mathrm{~d}$ in cold conditions. These times represent approximately equivalent physiological ages of the leaves at the two temperatures, representing nearly the same accumulated temperature (thermal time) above a base temperature of $0^{\circ} \mathrm{C}$. At $13 \mathrm{~d}$ and $22 \mathrm{~d}$ in warm and cold respectively the leaves had emerged from the sheath of the preceding leaf and were in the late phase of expansion; at $15 \mathrm{~d}$ and $26 \mathrm{~d}$ they were almost at maximum extension; at $17 \mathrm{~d}$ and $29 \mathrm{~d}$ extension had stopped and the leaves were mature; at $21 \mathrm{~d}$ and $36 \mathrm{~d}$ laminae were not visibly different from the previous sampling but by $24 \mathrm{~d}$ and $42 \mathrm{~d}$ the laminae were dying at the tips where yellowing was apparent, particularly with nitrogen deficiency. The phases will be referred to as expanding, almost mature, mature, ageing and early senescent leaves. Treatment combinations of cold and warm with low and high $\mathrm{N}$ are abbreviated in the text to $C-N, C+N, W-N$, and $W+N$.

\section{Analysis of enzyme activity}

The third leaf, used for all investigations, was collected $8 \mathrm{~h}$ into the photoperiod. Shoots were detached just above soil level and the cut bases placed in water. In the laboratory, $15 \mathrm{~min}$ later, the third leaf was detached at the ligule and immediately plunged into ice-cold water contained in a large Dewar flask. Leaves from different pots were bulked to provide samples of sufficient size.

\section{Preparation of leaf extracts}

Duplicate extracts were prepared for each treatment at a temperature between $0{ }^{\circ} \mathrm{C}$ and $4{ }^{\circ} \mathrm{C}$. Tissues were homogenized in the appropriate buffer using a pestle and mortar to release as much chlorophyll from cells as possible $(>90 \%)$. The extraction buffer for assay of glycolate oxidase, fructose bisphosphatase, serine-glyoxylate aminotransferase and glutamate-glyoxylate aminotransferase was $50 \mathrm{~mol} \mathrm{~m} \mathrm{~m}^{-3}$ imidazole (glyoxaline) $\mathrm{HCl}, \mathrm{pH} 7.5$, containing $0.5 \mathrm{~mol} \mathrm{~m} \mathrm{~m}^{-3}$ EDTA, $1.0 \mathrm{~mol} \mathrm{~m}^{-3}$ dithiothreitol and $0.1 \%(\mathrm{v} / \mathrm{v})$ Triton X-100. Substances of low molecular weight and inorganic ions in crude extracts were removed by the centrifugation desalting method of Helmerhorst and Stokes (1980) on $2 \times 1.0 \mathrm{~cm}$ columns of Sephadex G-25 pre-equilibrated with six times the bed volume of extraction buffer without Triton X-100.

Nitrate reductase and glutamine synthetase were assayed in an extract of $0.1 \mathrm{~g}$ fresh weight of tissues ground (for $2 \mathrm{~min}$ ) in $0.8 \mathrm{~cm}^{3}$ of cold, $100 \mathrm{~mol} \mathrm{~m}^{-3}$ potassium phosphate buffer $\mathrm{pH} 7.5$, containing $5.0 \mathrm{~mol} \mathrm{~m}^{-3}$ cysteine- $\mathrm{HCl}$ and $1.0 \mathrm{~mol} \mathrm{~m}{ }^{-3}$ EDTA with $3 \%(\mathrm{w} / \mathrm{v})$ bovine serum albumin (Brown, Small, and Wray, 1981). Homogenates were centrifuged at $10000 \times g$ for 3 min and the supernatants assayed immediately for nitrate reductase to avoid loss of enzyme activity.

Ribulose bisphosphate carboxylase (RuBPc) activity was measured after extraction of $0.1 \mathrm{~g}$ fresh weight of freshly collected material in $0.9 \mathrm{~cm}^{3}$ buffer of $20 \mathrm{~mol} \mathrm{~m}^{-3} \mathrm{Tris} / \mathrm{HCl}, \mathrm{pH} 8.2$, containing $20 \mathrm{~mol}$ $\mathrm{m}^{-3} \mathrm{MgCl}_{2}$ and $10 \mathrm{~mol} \mathrm{~m}^{-3}$ mercaptoethanol at 0 to $4{ }^{\circ} \mathrm{C}$. The homogenate was filtered through $25 \mu \mathrm{m}$ nylon mesh and used immediately for enzyme assay.

\section{Enzyme assays}

Each extract was assayed in duplicate. Measurements of absorption changes were made using a Pye Unicam SP8-100 U.V. spectrophotometer and ${ }^{14} \mathrm{C}$ was measured using an Intertechnique SL 4000 scintillation counter.

Glycolate oxidase activity (EC.1.1.3.1) was measured at $25^{\circ} \mathrm{C}$, by the method of Kerr and Groves (1975), using an oxygen electrode (Hansatech Ltd., Kings Lynn, Norfolk, England).

Fructose 1,6-bisphosphatase (FBPase) (EC.3.1.3.11) activity was measured by the method of Buchanan, Schurmann, and Kalberer (1971), and inorganic phosphate, released by the bisphosphatase reaction, by the method of Ames (1966). 
Serine-glyoxylate aminotransferase (SGAT) (EC.2.6.1.45) and glutamate-glyoxylate aminotransferase (GGAT) (EC.2.6.1.4) were assayed using the method of Cossins and Sinha (1965) by reacting ${ }^{14} \mathrm{C}$-glyoxylate with serine or glutamate and measuring the ${ }^{14} \mathrm{C}$ labelled glycine produced. Radioactive glycine was separated from labelled glyoxylate on a Dowex-1-acetate ion exchange resin column.

Nitrate reductase (NR) (EC.1.7.99.4) activity was assayed at $30^{\circ} \mathrm{C}$ by the method of Hageman and Reid (1980) and nitrate, produced in the reaction, was measured as described by Scholl, Harper, and Hageman (1974). The enzyme lost only $12 \%$ of its activity in $3 \mathrm{~h}$ at $0{ }^{\circ} \mathrm{C}$ in the extraction buffer; this rate of loss of activity was similar for all treatments and ages of leaves.

Glutamine synthetase (GS) (EC.6.3.1.2) was assayed at $30^{\circ} \mathrm{C}$ by the method of Wallsgrove, Lea, and Miflin (1979).

Ribulose 1,5-bisphosphate carboxylase (RuBPc-o, EC.4.1.1.39) activity was assayed by determining ${ }^{14} \mathrm{C}$ incorporation into acid stable material (Lorimer, Badger, and Andrews, 1977). Extracts $\left(10 \mathrm{~mm}^{3}\right)$, were mixed with $0.42 \mathrm{~cm}^{3} \mathrm{CO}_{2}$-free $119 \mathrm{~mol} \mathrm{~m}^{-2}$ Bicine buffer (pH 8.2) containing $23.8 \mathrm{~mol} \mathrm{~m}^{-3}$ $\mathrm{MgCl}_{2}$ mixed with $50 \mathrm{~mm}^{3} 100 \mathrm{~mol} \mathrm{~m}^{-3} \mathrm{NaH}^{14} \mathrm{CO}_{3}$, specific activity $37 \cdot 7 \mathrm{kBq} \mathrm{mol}^{-1}$, and the mixture heated for $25 \mathrm{~min}$ at $45^{\circ} \mathrm{C}$. The mixture was cooled to $25^{\circ} \mathrm{C}$ and the reaction started by addition of $\operatorname{RuBP}\left(10 \mathrm{~mm}^{3} 20 \mathrm{~mol} \mathrm{~m}^{-3}\right)$ and stopped after $1 \mathrm{~min}$ by addition of $0.2 \mathrm{~mm}^{3} 1 \times 10^{3} \mathrm{~mol} \mathrm{~m}^{-3}$ formic acid. Alternatively, extract and RuBP were added simultaneously to the mixture of buffer, $\mathrm{MgCl}_{2}$ and $\mathrm{NaH}^{14} \mathrm{CO}_{3}$ in $0.42 \mathrm{~cm}^{3}$ of solution, to avoid the effects of prolonged exposure to proteases in the extracts.

\section{Combined RuBP carboxylase-oxygenase assay}

Both enzyme activities were measured in reaction mixtures $\left(1.0 \mathrm{~cm}^{3}\right)$ at $25^{\circ} \mathrm{C}$, in an oxygen electrode vessel contained $0.84 \mathrm{~cm}^{3} \mathrm{CO}_{2}$-free buffer $\left(119 \mathrm{~mol} \mathrm{~m}{ }^{-3}\right.$ Bicine, $\left.\mathrm{pH} 8.2,10 \mathrm{~mol} \mathrm{~m}-3 \mathrm{MgCl}_{2}\right) .20 \mathrm{~mm}^{3}$ $\mathrm{KH}_{2} \mathrm{PO}_{4}\left(300 \mathrm{~mol} \mathrm{~m}^{-3}, \mathrm{pH} 7 \cdot 0\right), 20 \mathrm{~mm}^{3} \mathrm{NaH}^{14} \mathrm{CO}_{3}$ solution $\left(100 \mathrm{~mol} \mathrm{~m}^{-3}\right.$, specific activity $37.7 \mathrm{kBq}$ $\left.\mathrm{mol}^{-1}\right), 10 \mathrm{~mm}^{3}$ carbonic anhydrase solution $\left(1.0 \mathrm{mg}\right.$ crystaline enzyme in $1.0 \mathrm{~cm}^{3}$ assay buffer, equivalent to 27 Wilbur/Anderson units per $\left.10 \mathrm{~mm}^{3}\right)$ and $10 \mathrm{~mm}^{3} \mathrm{RuBP}$ solution $\left(40 \mathrm{~mol} \mathrm{~m}^{-3}\right.$ in $\left.\mathrm{H}_{2} \mathrm{O}\right)$ added in that order. When the $\mathrm{O}_{2}$ concentration was constant, the reaction was started by addition of $10 \mathrm{~mm}^{3}$ enzyme extract $\left(\sim 220 \mu \mathrm{g}\right.$ protein) and stopped after $45 \mathrm{~s}$ by addition of $50 \mathrm{~mm}^{3} 10 \mathrm{~N}$ formic acid. Duplicate $0.4 \mathrm{~cm}^{3}$ aliquots of reaction mixture were dried in vacuo over dessicant, then mixed with $10 \mathrm{~cm}^{3}$ toluene-Triton scintillator and counted. Carboxylase activity was calculated from the amount of acid stable ${ }^{14} \mathrm{C}$, and oxygenase activity from the $\mathrm{O}_{2}$ uptake over the assay period.

\section{Measurement of soluble proteins in extracts}

Total soluble protein in extracts was estimated using the method of Lowry, Rosebrough, Farr, and Randall (1951) with modifications (Bird, Cornelius, and Keys, 1982) using bovine serum albumin as standard.

\section{Measurements of amount of $R u B P c-o$ protein}

RuBPc-o protein in extracts was separated from other soluble proteins by horizontal gel electrophoresis in $1.0 \mathrm{~mm}$ thick $7.2 \%$ polyacrylamide ( $2 \%$ cross binding) in Tris-glycine (pH 8.9 buffer) and run at $7.0 \mathrm{~V} \mathrm{~cm}^{-1}$. Proteins were stained $(17 \mathrm{~h})$ in $0.05 \%$ Coomassie brilliant blue in $12 \%$ TCA and destained in $12 \%$ TCA for $48 \mathrm{~h}$. Individual gel tracks were scanned at $590 \mathrm{~nm}$ and areas quantified from the spectophotometer traces by weighing peak areas. Amounts of RuBPc-o were calculated by comparison with standards of purified wheat enzyme on the same gel.

\section{Measurement of chlorophyll}

Chlorophyll was measured by the method of Arnon (1949).

\section{Amino acids and nitrate content}

Samples of the 3rd leaf were extracted for analysis of amino acids, using the method of Redgewell (1980). Leaves were frozen in liquid nitrogen, then extracted in cold MCFW (methanol: chloroform: formic acid: water; $12 / 5 / 2 / 1$, by vol.) and the organic and aqueous phases separated by addition of chloroform and water. The aqueous phase was dried over $\mathrm{KOH}$ under vacuum to remove formic acid, then dissolved in water. The extract was passed through Sephadex ion-exchangers $\mathrm{SP}\left(\mathrm{H}^{+}\right)$and QAE $\left(\mathrm{COOH}^{-}\right)$to separate the neutral (sugar) fraction from the amino acids (retained on the SP column) and phosphate esters and organic acids (retained on the QAE column). Amino acids were eluted from the SP column with $200 \mathrm{~mol} \mathrm{~m}^{-3} \mathrm{NH}_{4} \mathrm{OH}$; total acids were measured by the method of Yemm and Cocking (1955). 
Nitrate ion concentration was measured on samples of the whole $3 \mathrm{rd}$ leaf, oven-dried at $80^{\circ} \mathrm{C}$ for $24 \mathrm{~h}$ and ground. Nitrate was extracted from the dried powder by boiling with distilled water for $3 \mathrm{~min}$, and analysed by Technicon autoanalyser.

\section{RESULTS}

\section{Soluble protein}

The soluble protein content, per unit area, of expanding leaves was similar in plants grown in the $\mathrm{C}+\mathrm{N}, \mathrm{C}-\mathrm{N}$ and $\mathrm{W}+\mathrm{N}$ treatments but those in $\mathrm{W}-\mathrm{N}$ had less soluble protein (Fig. 1a). As the leaves aged, proteins increased slightly in the $\mathrm{C}+\mathrm{N}$ but decreased in $\mathrm{C}-\mathrm{N}$ leaves. The protein content of leaves in early senescence differed 3 -fold between $-\mathrm{N}$ and $+\mathrm{N}$ treatments in the cold but the difference was much smaller in the warm conditions.

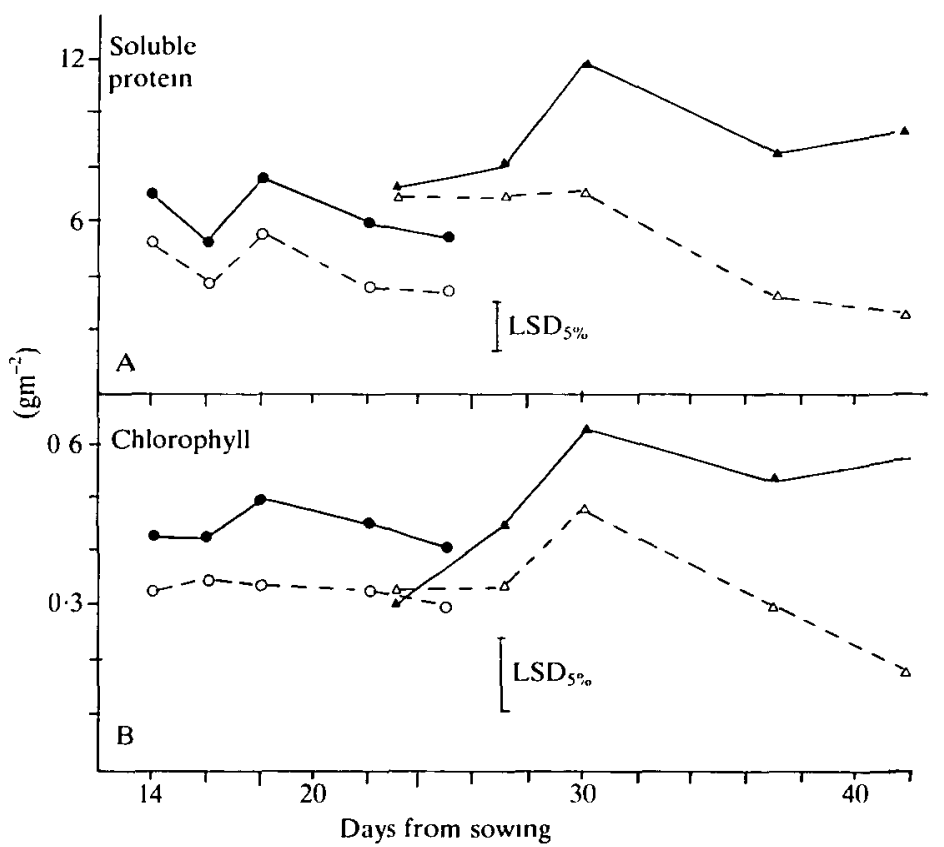

FIG. 1. Effects of temperature and nitrate supply on (a) soluble protein and (b) chlorophyll per unit area of the 3rd leaf of wheat grown at $13 / 10^{\circ} \mathrm{C}-\mathrm{N}, \Delta 13 / 10^{\circ} \mathrm{C}+\mathrm{N}, \Delta, 23 / 13^{\circ} \mathrm{C}-\mathrm{N}, 0,23 / 13^{\circ} \mathrm{C}+\mathrm{N}, \bullet$. The means are from duplicate measurements made on extracts from two replicate samples of leaf tissue. Bar represents least significant difference $(P=5 \%)$.

Protein content was also determined in another experiment, comparing the effects of light on components of leaves grown in the two water and two temperature regimes. Mature leaves grown in the cooler temperature contained $26 \%$ more RuBPc-o protein (Table 1) than those grown in warm conditions when averaged over all nitrogen and light treatments. Growth in bright light increased RuBPc-o protein compared to dim light by $14 \%$ in the cold and $36 \%$ in the warm but only with additional nitrate. In dim light nitrate increased RuBPc-o protein by $20 \%$ in the cold and $45 \%$ in the warm but in bright light the increases were $40 \%$ in the cold and $109 \%$ in the warm conditions respectively. The relationship of RuBPc-o protein to total soluble protein was: RuBPc-o protein $\left(\mathrm{g} \mathrm{m}^{-2}\right)=-0.387+0.734 \times$ soluble protein $\left(\mathrm{g} \mathrm{m}^{-2}\right)$; $r=0.96$, i.e. a ratio of about $60 \%$ in tissues grown with $600 \mu \mathrm{mol}$ quanta $\mathrm{m}^{-2} \mathrm{~s}^{-1}$ illumination. 
TABLE 1. RUBP carboxylase protein $\left(\mathrm{g} \mathrm{m}^{-2}\right), R u B P$ carboxylase and oxygenase activities (umol g protein $\left.{ }^{-1} s^{-1}\right), \mathrm{CO}_{2}$ saturated $\mathrm{RuBPc}$ activity $\left(\mu \mathrm{mol} \mathrm{m} \mathrm{m}^{-2} \mathrm{~s}^{-1}\right.$ ) and the ratio of carboxylase to oxygenase activity measured at $25^{\circ} \mathrm{C}$ in fully expanded $3 \mathrm{rd}$ leaf of wheat, with different light, temperature and nitrate supply during growth

The purified enzyme was assayed for both activities in the combined assay described in the methods section and $\mathrm{CO}_{2}$ saturated $\mathrm{RuBPc}$ activity was assayed immediately after extraction at $13{ }^{\circ} \mathrm{C}$.

\begin{tabular}{|c|c|c|c|c|c|c|c|c|c|}
\hline & \multicolumn{8}{|c|}{ Growth temperature } & \multirow[t]{4}{*}{ (s.e.d.) } \\
\hline & \multicolumn{4}{|c|}{$13 / 10^{\circ} \mathrm{C}$} & \multicolumn{4}{|c|}{$23 / 18^{\circ} \mathrm{C}$} & \\
\hline & \multicolumn{2}{|c|}{$\begin{array}{l}350 \mu \mathrm{mol} \\
\text { quanta } \mathrm{m}^{-2} \mathrm{~s}^{-1}\end{array}$} & \multicolumn{2}{|c|}{$\begin{array}{l}600 \mu \mathrm{mol} \\
\text { quanta } \mathrm{m}^{-2} \mathrm{~s}^{-1}\end{array}$} & \multicolumn{2}{|c|}{$\begin{array}{l}350 \mu \mathrm{mol} \\
\text { quanta } \mathrm{m}^{-2} \mathrm{~s}^{-1}\end{array}$} & \multicolumn{2}{|c|}{$\begin{array}{l}600 \mu \mathrm{mol} \\
\text { quanta } \mathrm{m}^{-2} \mathrm{~s}^{-1}\end{array}$} & \\
\hline & $-\mathbf{N}$ & $+N$ & $-\mathbf{N}$ & $+\mathrm{N}$ & $-\mathbf{N}$ & $+N$ & $-N$ & $+N$ & \\
\hline $\begin{array}{l}\text { RuBPc-o } \\
\text { protein }\end{array}$ & $4 \cdot 41$ & $5 \cdot 30$ & 4.27 & 6.03 & 2.96 & $4 \cdot 30$ & $2 \cdot 80$ & $5 \cdot 86$ & $(0.21)$ \\
\hline $\begin{array}{l}\mathrm{CO}_{2} \text {-saturated } \\
\text { carboxylase } \\
\text { activity at }\end{array}$ & & & & & & & & & \\
\hline $\begin{array}{c}13{ }^{\circ} \mathrm{C} \\
\text { Carboxylase }\end{array}$ & $14 \cdot 6$ & 17.9 & $15 \cdot 7$ & $22 \cdot 2$ & $14 \cdot 4$ & $19 \cdot 0$ & $11 \cdot 5$ & $19 \cdot 3$ & $(1 \cdot 2)$ \\
\hline $\begin{array}{l}\text { specinc } \\
\text { activity }\end{array}$ & $3 \cdot 32$ & $3 \cdot 37$ & 3.67 & $3 \cdot 38$ & $4 \cdot 88$ & $4 \cdot 41$ & 4.09 & 3.97 & $(0 \cdot 14)$ \\
\hline $\begin{array}{l}\text { Oxygenase } \\
\text { specific } \\
\text { activity }\end{array}$ & & & $1 \cdot 17$ & 1.04 & & & $1 \cdot 14$ & 1.28 & $(0 \cdot 1)$ \\
\hline Ratio c/o & & & $3 \cdot 1$ & $3 \cdot 2$ & & & $2 \cdot 9$ & $3 \cdot 1$ & $(0.05)$ \\
\hline
\end{tabular}

\section{Chlorophyll content}

Total chlorophyll per unit leaf area was greater with added nitrate than without in warm conditions, and remained constant throughout the leaf's life. In cold conditions, initial concentrations were similar with and without added nitrate (and similar to $\mathrm{W}-\mathrm{N}$ ); chlorophyll increased as leaves matured and remained at a high concentration as they aged in $\mathrm{C}+\mathrm{N}$ grown plants, but it tended to decrease with age in $\mathrm{C}-\mathrm{N}$. Differences in chlorophyll content were substantial; there was almost twice as much in the $\mathrm{C}+\mathrm{N}$ compared with the $\mathrm{C}-\mathrm{N}$ treatment in leaves approaching senescence. Chlorophyll content was closely related to the soluble protein over all treatments; chlorophyll $\left(\mathrm{g} \mathrm{m}^{-2}\right)=0.174+0.041 \times$ soluble protein $\left(\mathrm{g} \mathrm{m}^{-2}\right), r=0.85$.

\section{Enzyme activities}

The photosynthetic carbon reduction cycle (PCR) enzymes, RuBPc and FBPase (Fig. 2a, b) had greater activity with added nitrate than without, throughout the sampling period. RuBPc activity was similar in leaves grown at the two temperatures but loss of activity with time was greatest in the $\mathrm{C}-\mathrm{N}$ treatment. RuBPc activity per unit leaf area increased with increasing protein content (Fig. 3) approximately linearly at low protein content but not at higher. In the experiment (Table 1) comparing the effects of light together with nitrate supply and temperature, the amount of RuBPc activity per unit leaf area was greater in leaves with added $\mathrm{N}$ and in bright light. Specific activity (activity per unit of protein) of RuBPc (Table 1) 


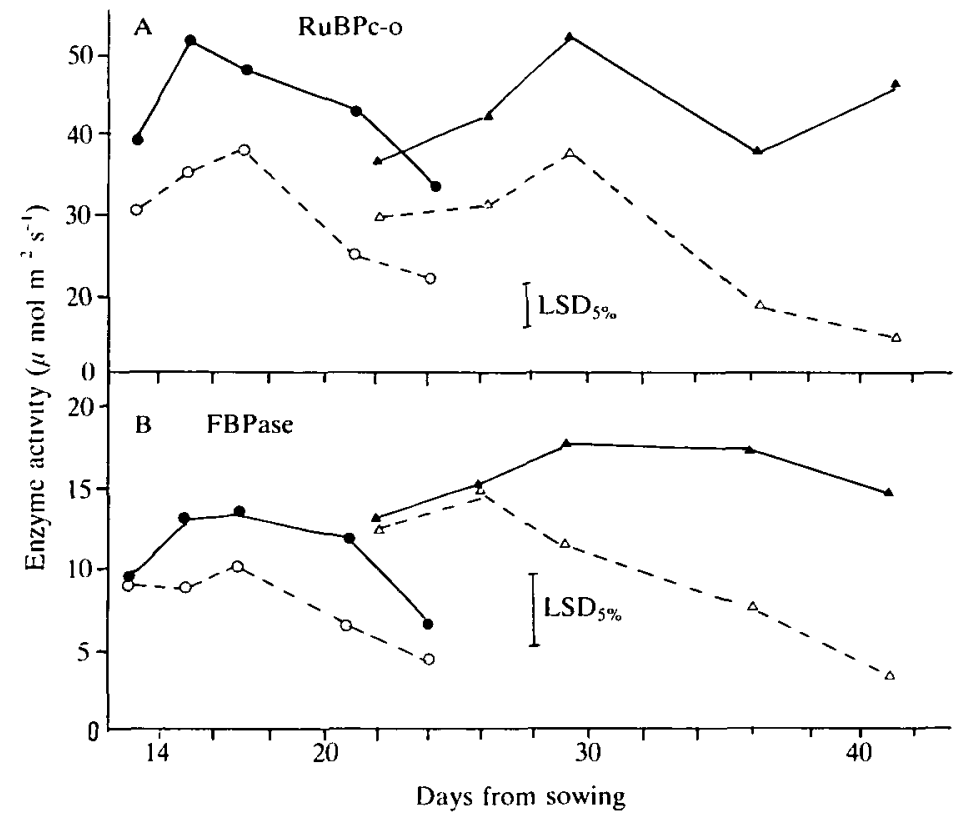

FIG. 2. Effects of temperature and nitrate supply on enzyme activity of the 3rd leaf of wheat, with age, grown under the conditions described in the legend to Fig. 1. (a) Ribulose bisphosphate carboxylaseoxygenase assayed at $25^{\circ} \mathrm{C}$ after activation at $45^{\circ} \mathrm{C}$ for $25 \mathrm{~min}$ with $20 \mathrm{~mol} \mathrm{~m}^{-3} \mathrm{MgCl}_{2}$ and $10 \mathrm{~mol} \mathrm{~m}^{-3}$ $\mathrm{NaH}^{14} \mathrm{CO}_{3}$. (b) Fructose bisphosphatase. Means of duplicate measurements made on extracts from each of two replicate samples of tissue. Bar represents least significant difference $(P=5 \%)$.

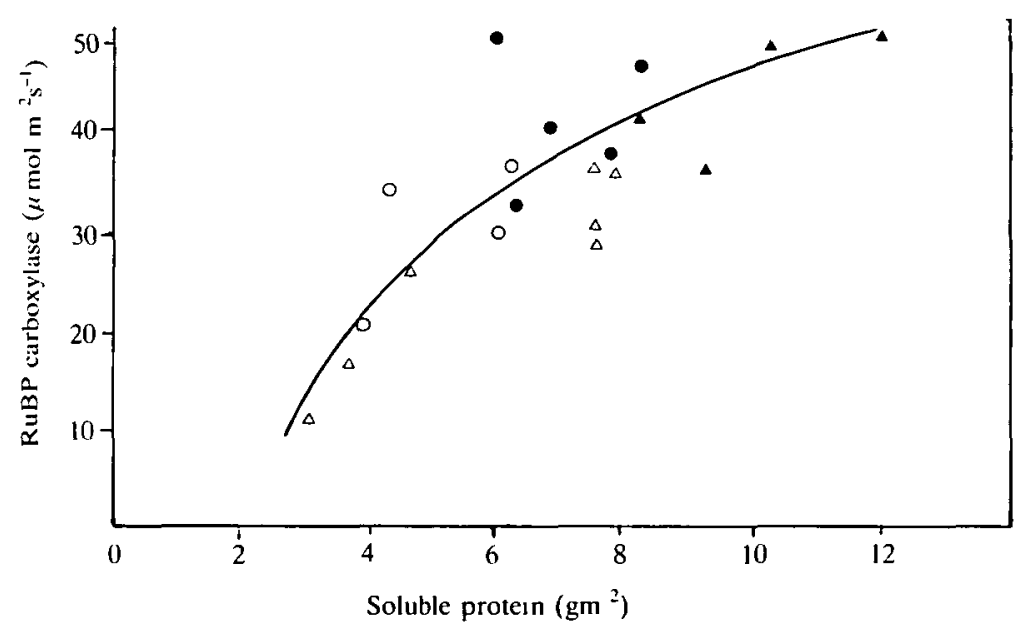

FIG. 3. Activity of RuBP carboxylase (from Fig. 1) in relation to total soluble protein for wheat leaves grown under conditions described in Fig. 1, symbols as in Fig. 1.

was smaller in cool than warm growth temperatures but was similar in leaves from different illumination. Specific activity was slightly greater with added $\mathrm{N}$ in the cold but without it in the warm; it was greatest in tissues with the smaller RuBPc-o and total protein content. Specific activity ranged from 4.5 to $3.2 \mu$ mol g RuBPc-o protein ${ }^{-1} \mathrm{~s}^{-1}$ whilst protein content changed from 6 to $12 \mathrm{~g} \mathrm{~m}^{-2}$. The ratio of RuBP carboxylase to RuBP oxygenase activity, 
measured on extracts of leaves grown in bright light (Table 1), was greater (but not significantly so) in the warm conditions and without additional nitrate.

FBPase activity (Fig. 2b) increased slightly in $+\mathrm{N}$ treatments as the leaves matured and decreased as they started to senesce, particularly in the $-\mathbf{N}$ treatments. FBPase activity was greater in cold- than in the warm-grown leaves at most stages of leaf development, but decreased with age faster in the $\mathrm{C}-\mathrm{N}$ than in the other treatments.

Nitrate reductase (NR) activity was highest in expanding or almost mature leaves in all treatments (Fig. 4a). Activity was greatest in the $\mathrm{C}+\mathrm{N}$ and smallest in the $\mathrm{W}-\mathrm{N}$ grown leaves and maximum values were greater in the cold with both low and high $\mathrm{N}$, suggesting that cold conditions stimulate development of activity. The NR activity decreased markedly as leaves aged in all treatments and, by the start of leaf senescence, it ranged from $c .5 \%$ (in $\mathrm{C}-\mathrm{N}$ ) to $25 \%$ (in $\mathrm{W}+\mathrm{N}$ ) of the maximum.

Glutamine synthetase (GS; Fig. 4b) and SGAT and GGAT (Fig. 4c, d) activities were stimulated by additional nitrate in both the cold and warm conditions particularly at the higher temperature in the case of GS. GS and GGAT decreased with leaf age in low nitrate treatments, whereas SGAT was almost constant, and even increased in the $\mathrm{C}+\mathrm{N}$ treatments.

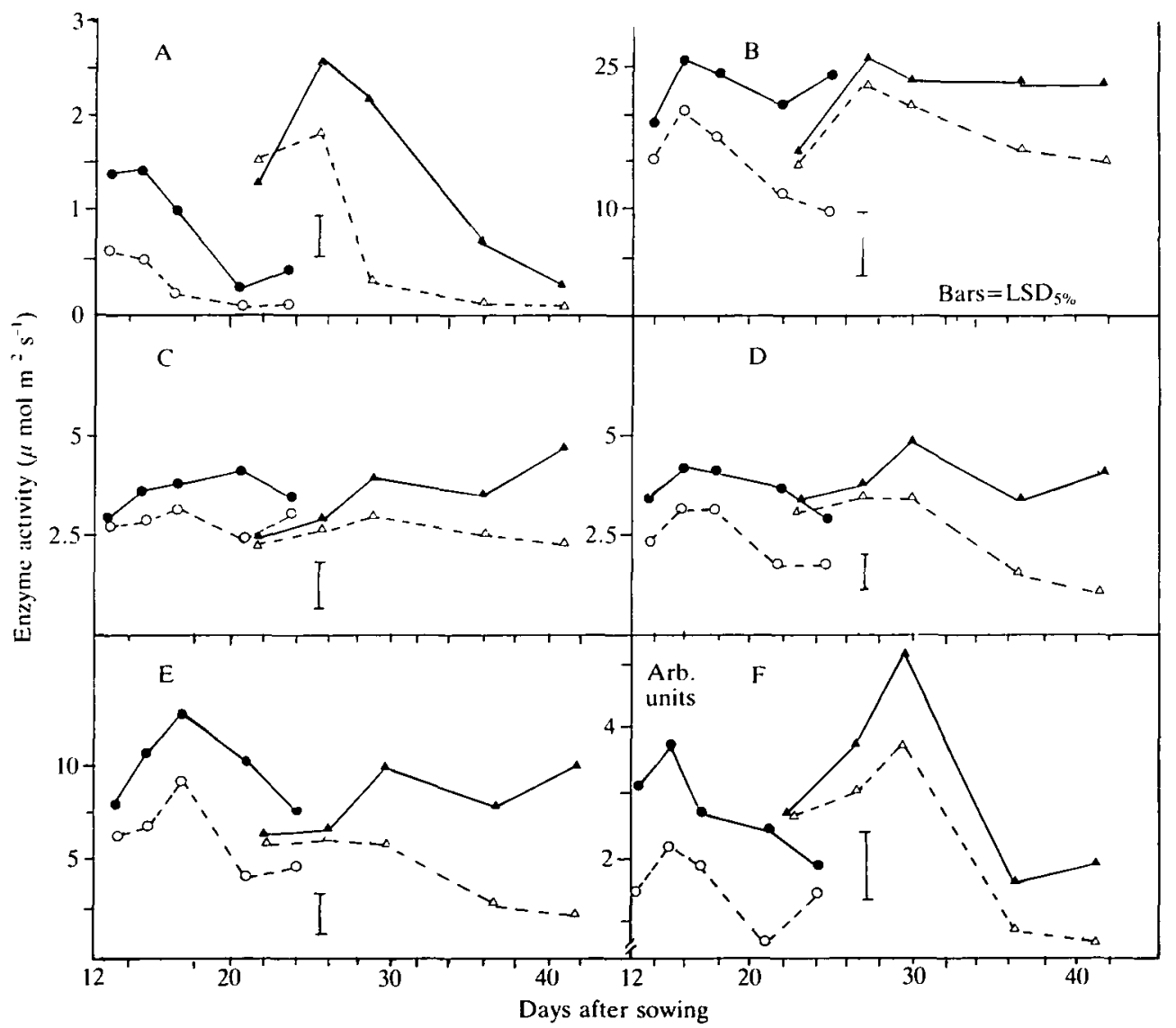

FIG. 4. Effects of temperature and nitrate supply on activity of enzymes in leaves of wheat grown under the conditions described in the legend to Fig. 1. (a) Nitrate reductase (b) glutamine synthetase (c) serine glyoxylate aminotransferase (d) glutamate-glyoxylate aminotransferase (e) glycolate oxidase (f) carbonic anhydrase. Means of duplicate measurements made on extracts from each of two replicate samples of tissue. Bar represents least significant difference $(P=5 \%)$. 


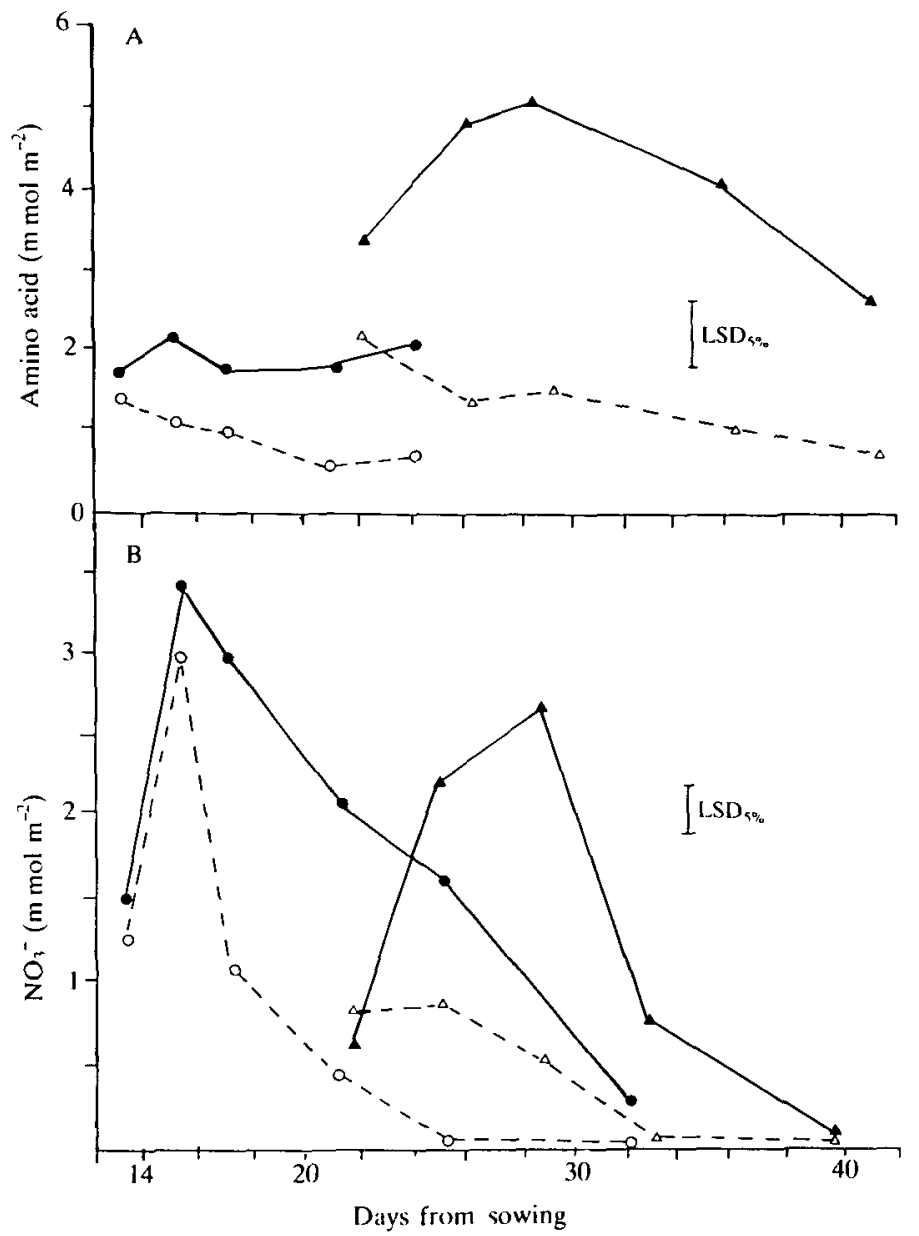

FIG. 5. (a) Total soluble amino acid content and (b) nitrate content of the 3 rd leaf of wheat plants grown under conditions described in the legend to Fig. 1. Bar represents least significant difference $(P=5 \%)$.

The activity of GS was 5-fold greater than that of the other two enzymes. Compared to nitrate reductase activity, GS, SGAT and GGAT maintained high activities throughout the life of the leaf. Temperature and nitrate supply did not interact to any marked extent in changing enzyme activity.

Glycolate oxidase activity (Fig. 4e) was greater in warm conditions than in cold at leaf maturity and greater with high nitrate compared to low. Activity decreased as the leaves aged, particularly in the low nitrate treatments. Carbonic anhydrase (Fig. 4f) increased in activity up to leaf maturity in all conditions and then decreased with leaf age. Activity was stimulated in cool conditions and also by increased nitrate supply.

Free amino acids and nitrate

Total free amino acid content (Fig. 5a) was greater in cool conditions and with additional nitrate, although differences between $\mathrm{W}-\mathrm{N}$ and $\mathrm{C}-\mathrm{N}$ plants were small. Changes in amino acid content with time were most marked in the $\mathrm{C}+\mathrm{N}$ treatment with amino acid content increasing substantially from emergence to full appearance of the lamina. There was a loss of 
amino acids in the low nitrate treatments throughout development of the leaves; in the $\mathrm{W}+\mathrm{N}$ condition, the concentration of amino acids remained almost constant.

\section{DISCUSSION}

\section{Environmental conditions}

Plants were not extremely nitrogen deficient in the low nitrate treatments. Nitrate concentration in the pots was calculated as $1.2 \mathrm{~mol} \mathrm{~m}^{-3}$ in the low and $6.0 \mathrm{~mol} \mathrm{~m}^{-3}$ in the high $\mathrm{N}$ treatments at sowing and about 0.6 and $3.0 \mathrm{~mol} \mathrm{~m} \mathrm{~m}^{-3}$ respectively just after each bi-weekly addition of nitrate. The high nitrogen treatment increased growth substantially (Lawlor et al., in preparation) and changed the chemical and biochemical composition of the leaves. Total nitrogen content in dry matter was approximately $2 \cdot 8 \%$ with low $\mathrm{N}$ and $4 \cdot 2 \%$ with high $\mathrm{N}$ and the leaf nitrate concentration exhibited a 3 -fold range in mature leaves. Nitrogen supply to the growing leaf may have fluctuated in our experiment because of the method of application; a relatively high concentration of soil nitrate initially would have decreased through uptake by the plant, until replenished at regular intervals by concentrated nitrate solution.

Temperatures were sufficiently contrasted to affect leaf growth and composition (Lawlor et al., 1987a,b). The temperature optima for most plant processes is above $20^{\circ} \mathrm{C}$, although the higher temperature $\left(23^{\circ} \mathrm{C}\right.$ day $/ 18^{\circ} \mathrm{C}$ night) is warm for a cereal crop selected for European conditions and even the $13^{\circ} \mathrm{C}$ day $/ 10^{\circ} \mathrm{C}$ night is warmer than that normally experienced by such a crop early in its growth when the third leaf is formed. Leaves were sampled in the two treatments at nearly equivalent physiological stages which occurred at similar thermal times after sowing. Thus $13 \mathrm{~d}$ in warm conditions (mean temperature $21.3{ }^{\circ} \mathrm{C}$ ) and $22 \mathrm{~d}$ in cool (mean temperature $12^{\circ} \mathrm{C}$ ) produced plants of similar physiological age and corresponded to 277 and 264 day ${ }^{\circ} \mathrm{C}$ (above $0{ }^{\circ} \mathrm{C}$ ) respectively; similarly 24 and $42 \mathrm{~d}$ are equivalent to 512 and 508 day ${ }^{\circ} \mathrm{C}$ respectively and gave plants of comparable senescence stage.

The photosynthetically active radiation $(400-700 \mathrm{~nm})$ supplied to the plants over the $16 \mathrm{~h}$ photoperiod in most experiments was equivalent to the total for an average summer's day in the U.K. but the maximum photon flux was smaller than peak photon fluxes $(>1500 \mu \mathrm{mol}$ quanta $\mathrm{m}^{-2} \mathrm{~s}^{-1}$ ) occurring in the field. Where photon fluxes of 350 and $600 \mu \mathrm{mol}$ quanta $\mathrm{m}^{-2} \mathrm{~s}^{-1}$ were compared, they changed leaf composition and there was interaction with $\mathrm{N}$ supply and temperature.

\section{Nitrate content, nitrate reductase activity and amino acid content}

Nitrate content of the third leaf in these experiments exhibited four main features; maximum accumulation at about leaf maturity; rapid and substantial decrease as the leaf aged in both temperatures; larger content with additional nitrate in older leaves; smaller content with cool growth temperature. Nitrate reductase activity (which is rate limiting for nitrate reduction) was greater in cool than warm conditions, suggesting that nitrate content may be regulated more by enzyme activity than by nitrate uptake. Photosynthetic rate in young leaves was similar in all treatments (Lawlor et al., 1987a), so reductant supply (generated in the light reactions) for nitrate assimilation was unlikely to have been limiting. Large nitrate content in leaves from $\mathrm{W}+\mathrm{N}$ treatments would, on the basis of this argument, be caused by low nitrate reductase activity rather than greater rate of uptake. Nitrate reductase activity is induced by nitrate (Hageman, 1979) but in this experiment NR activity and concentration of nitrate were not closely related, particularly in warm conditions, young leaves with additional nitrate supply had similar nitrate reductase activity to, but larger nitrate content than, leaves from cool conditions. The $\mathrm{W}-\mathrm{N}$ treatment had low nitrate reductase activity but similar nitrate content to $\mathrm{W}+\mathrm{N}$. Lack of correlation is perhaps 


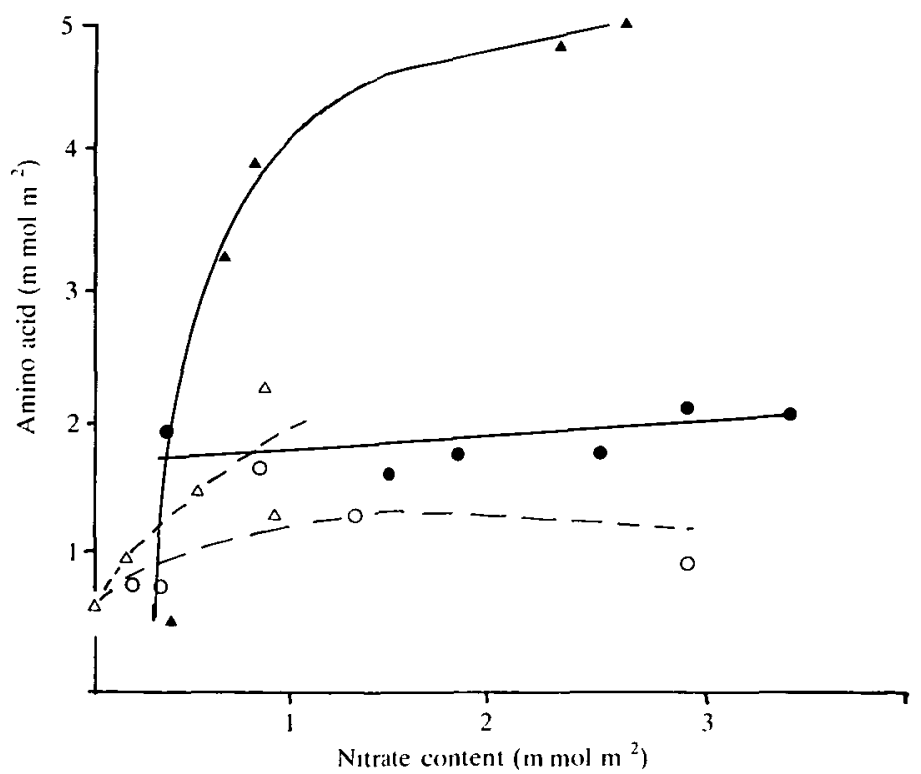

FIG. 6. Relationship between nitrate and amino acid contents of the 3rd leaf of wheat growing with different temperature and nitrate supply; conditions and symbols as in Fig. 1.

expected as total tissue nitrate concentration may not reflect conditions at the site of enzyme synthesis. Cool temperature increased the NR activity greatly, compared with GS or SGAT, suggesting a differential effect of temperature on synthesis of these enzymes. Nitrate reductase activity and nitrate content decreased similarly as leaves aged but it is not established if inhibition of enzyme synthesis or slower nitrate uptake is the controlling mechanism. Decreased uptake of nitrate into leaves may prevent inefficient use of $\mathrm{N}$ in leaves which are losing photosynthetic capacity, and enable younger tissues to compete for nitrate (Nevins and Loomis, 1970).

Amino acid content of the tissue was substantially greater in cool than warm conditions and with additional nitrate, and was related to the NR activity. As nitrate changed with leaf age, the amino acid content changed similarly (Fig. 6). The decrease in nitrate and amino acids was rather greater than the decrease in photosynthesis (Lawlor et al., 1987a). Ammonia produced from nitrate is toxic to cell functions, and there is close coupling with amino acid synthesis so it is to be expected that greater NR activity would result in larger amino acid content. Provision of carbon from photosynthesis for amino acid production would probably have been similar in different treatments as the rates of assimilation in young leaves did not differ greatly (Lawlor et al., 1987a). The relationship between total soluble amino acids and nitrate depends on uptake and reduction of nitrate, on the rate of amino acid synthesis and on the rate of their consumption in protein formation (Beevers and Hageman, 1980). Rate of protein synthesis was probably slowed by about $35 \%$ in cool conditions, the amount by which growth was decreased. However, cool temperature increased nitrate reductase activity; it was $c .70 \%$ greater in $\mathrm{C}+\mathrm{N}$ conditions so the 3 -fold increase in amino acids may be ascribed to nitrate supply and enzyme activity, rather than inhibition of growth.

\section{Chlorophyll, soluble protein and $R u B P c-o$ protein content}

Chlorophyll content of younger leaves was similar in all except the $\mathrm{W}+\mathrm{N}$ treatment, suggesting that conditions were similar for thylakoid development. However, in older leaves 
the much larger content of chlorophyll in $\mathrm{C}+\mathrm{N}$ compared to $\mathrm{C}-\mathrm{N}$ may reflect greater remobilization of thylakoid structure; the similar chlorophyll content in the low $\mathrm{N}$ treatments, implies that there are structural components of the thylakoids which are also remobilized late in senescence (Thomas and Stoddart, 1980).

Total soluble protein content of young leaves was similar in all except the $W-N$ treatment, which had the smallest content. In older leaves protein, chlorophyll and amino acids decreased, particularly in cool conditions with low $\mathrm{N}$, suggesting that remobilization of nitrogen occurred from thylakoids and other parts of the cell. Bright light increased protein content with additional $\mathrm{N}$, particularly at the cooler temperature. Thus environmental factors (varying within a relatively narrow range compared to the field) modify protein and pigment considerably. We measured soluble protein contents 2-3 times larger than those observed by Schmitt and Edwards (1981) and a constant chlorophyll to soluble protein ratio, in agreement with Evans (1983), who found that the ratio of chlorophyll to total nitrogen was constant throughout senescence. He also found greater amounts of soluble protein and chlorophyll in leaves of wheat grown in summer compared to winter, possibly due to brighter light (although this could not be separated from the effect of warmer temperatures), and lower chlorophyll to nitrogen ratio. Friedrich and Huffaker (1980) also found the ratio of chlorophyll to protein to be relatively constant until late in senescence of barley leaves.

Control of enzyme formation is not well understood in relation to conditions in vivo (Huffaker, 1983). RuBPc-o protein, where this was measured, was 60-70\% of the soluble protein in our experiments, similar to other studies (Evans, 1983; Makino, Mae, and Ohira, 1984; Huffaker, 1983; Wittenbach, 1979), and was not affected by treatment or leaf age. The range of RuBPc-o mass per unit leaf area was from $6.03 \mathrm{~g} \mathrm{~m}^{-2}$ with additional nitrate supply, cool temperature and bright light to $2.8 \mathrm{~g} \mathrm{~m}^{-2}$ in warm and bright light with deficient $\mathrm{N}$. The amounts of RuBPc-o protein per unit of chlorophyll ranged from $c .9$ to $13 \mathrm{~g} \mathrm{~g}^{-1}$ in our experiments; Perchorowicz, Raynes, and Jensen (1981) measured 7.8 to $15 \mathrm{~g} \mathrm{~g}^{-1}$ in young wheat leaves. We observed that the RuBPc-o to protein ratio was almost constant with increasing protein. However, Natr (1975) and Wittenbach (1979) demonstrated that, with increasing $\mathrm{N}$ supply, RuBPc-o did not increase in proportion to total protein. Friedrich and Huffaker (1980) observed that RuBPc-o decreased as a proportion of total protein in barley leaves. Evidence suggests that nitrogen deficiency limits the formation of proteins in the chloroplast thylakoids as well as stroma. The possibility that RuBPc-o functions as a storage protein has not received support from studies on soybean (Wittenbach, Franceschi, and Giaquinta, 1984).

\section{Enzyme activity}

RuBPc activity measured in crude extracts at $13{ }^{\circ} \mathrm{C}$ was $40 \mathrm{nmol} \mu \mathrm{g} \mathrm{chl}{ }^{-1} \mathrm{~s}^{-1}$; Perchorowicz et al. (1981) determined $76 \mathrm{nmol} \mu \mathrm{g} \mathrm{chl}^{-1} \mathrm{~s}^{-1}$ at $25^{\circ} \mathrm{C}$. Correction of our data to $25{ }^{\circ} \mathrm{C}$ gave values of between 58 and $126 \mathrm{nmol} \mathrm{mg} \mathrm{chl}{ }^{-1} \mathrm{~s}^{-1}$. RuBPc-o activity was proportional to the amount of protein, so that the mean specific activity was $3.74 \mu \mathrm{mol} g$ RuBPc-o protein ${ }^{-1} \mathrm{~s}^{-1}$ (Table 1 ) corresponding to approximately $6.4 \mu \mathrm{mol} \mathrm{g} \mathrm{RuBPc-0}$ protein $^{-1} \mathrm{~s}^{-1}$ at $25{ }^{\circ} \mathrm{C}$. This was lower than the $30 \mu \mathrm{mol} \mathrm{g} \mathrm{RuBPc-o}$ protein ${ }^{-1} \mathrm{~s}^{-1}$ determined by Schmidt, Cornelius, Burton, Parry, Millard, Keys, and Gutteridge (1984) for purified protein under optimal conditions. Makino et al. (1984) measured specific activity of $8.0 \mu \mathrm{mol} \mathrm{g} \mathrm{RuBPc}-\mathrm{o}$ protein ${ }^{-1} \mathrm{~s}^{-1}$ in rice.

Activities of FBPase, GS, GGAT, glycolate oxidase and carbonic anhydrase in young leaves were generally related to total soluble protein. RuBPc-o activity tended to decrease at larger protein content and SGAT activity remained large at low protein content. As leaves 
aged, activity of RuBPc-o decreased in proportion to soluble protein, but nitrate reductase decreased more; possibly this reflects the very slow turn-over of RuBPc-o in comparison to the rapid metabolism of nitrate reductase (Huffaker, 1983). Fructose bisphosphatase activity was linearly related to the RuBPc activity by FBPase $\left(\mu \mathrm{mol} \mathrm{m} \mathrm{m}^{-2} \mathrm{~s}^{-1}\right)=11 \cdot 39+0.24 \times$ $\operatorname{RuBPc}\left(\mu \mathrm{mol} \mathrm{m} \mathrm{m}^{-2} \mathrm{~s}^{-1}\right) ; r=0 \cdot 86$. This may be expected of another PCR cycle enzyme and suggests that production of enzymes is closely linked. The stoichiometry of the PCR cycle requires, for efficient, balanced function (Keys et al., 1978) that the amount and activity of enzymes would alter in proportion both during development and during ageing. Even enzymes associated with, but not part of, the PCR cycle might be expected to be regulated similarly, to ensure efficient carbon assimilation. Thus carbonic anhydrase was proportional to RuBPc activity (carbonic anhydrase (arbitrary units) $=-0.009+0.02 \times \mathrm{RuBPc}$ activity $\left.\left(\mu \mathrm{mol} \mathrm{m}^{-2} \mathrm{~s}^{-1}\right) ; r=0.8\right)$; the large scatter in the data may reflect its role in parts of the cell other than the chloroplast.

The proportion of photorespiration to photosynthesis is determined by the ratio of RuBPc to $\mathrm{RuBPo}$ activities (specificity factor), and on the $\mathrm{CO}_{2} / \mathrm{O}_{2}$ concentration ratio and temperature at the active site. Low $\mathrm{CO}_{2} / \mathrm{O}_{2}$ ratio and warm conditions increase the proportion of photorespiration to photosynthesis. The specificity factor (measured under standard conditions) was not altered by growth conditions, as expected from the studies of Bird et al. (1982). Carbon flux into the glycolate pathway from the oxygenase reaction in our experiment would be almost constant, as temperature and gas concentrations in the leaf were similar in all treatments. Proportionality was observed between RuBPc and glycolate oxidase (glycolate oxidase activity $\left(\mu \mathrm{mol} \mathrm{m}^{-2} \mathrm{~s}^{-1}\right)=1.23+0.0174 \times \mathrm{RuBPc}$ activity $(\mu \mathrm{mol}$ $\left.\left.\mathrm{m}^{-2} \mathrm{~s}^{-1}\right) ; r=0.8\right)$, glutamine synthetase activity $\left(\mu \mathrm{mol} \mathrm{m} \mathrm{m}^{-2} \mathrm{~s}^{-1}\right)=1.56+0.013 \times \mathrm{RuBPc}$ activity $\left(\mu \mathrm{mol} \mathrm{m} \mathrm{m}^{-2} \mathrm{~s}^{-1}\right) ; r=0.67$ and GGAT activity $\left(\mu \mathrm{mol} \mathrm{m} \mathrm{m}^{-2} \mathrm{~s}^{-1}\right)=0.774+0.015$ RuBPc activity $\left(\mu \mathrm{mol} \mathrm{m} \mathrm{m}^{-2} \mathrm{~s}^{-1}\right) ; r=0.82$. Glutamine synthetase reassimilates ammonia produced in glycine decarboxylation and maintains flux through the glycolate pathway and carbon assimilation; perhaps the proportionality between the activities indicates the requirement for efficient carbon and nitrogen recycling under normal atmospheric conditions of $\mathrm{O}_{2}$ and $\mathrm{CO}_{2}$ partial pressure (Keys et al., 1978). Activity of the peroxisomal enzyme SGAT decreased less than that of RuBPc (SGAT activity $\left(\mu \mathrm{mol} \mathrm{m}^{-2} \mathrm{~s}^{-1}\right)=3 \cdot 13+$ $0.009 \times$ RuBPc activity $\left.\left(\mu \mathrm{mol} \mathrm{m}^{-2} \mathrm{~s}^{-1}\right) ; r=0.73\right)$, GS or GGAT with increasing leaf age. Differences between GGAT and SGAT may reflect the role of peroxisomes during senescence. Our data suggests that the enzymes associated with photosynthesis and photorespiration and related nitrogen metabolism, are closely linked in formation. One corollary of this is that the capacities of different parts of the photosynthetic system and the balance between them is genetically controlled and photosynthesis, as a whole, is regulated to provide optimum rates of photosynthesis in particular environments. If gross imbalance were to occur, then metabolism would be disrupted and effective biological function destroyed.

The greatest difference in activities, over the treatments we imposed, was between that of nitrate reductase and those of the other components of the tissue. Nitrate reductase activity showed little relation to total soluble protein or to RuBPc activity (NR activity ( $\mu \mathrm{mol} \mathrm{m} \mathrm{m}^{-2}$ $\left.\mathrm{s}^{-1}\right)=-0.089+0.005 \times \operatorname{RuBPc}$ activity $\left.\left(\mu \mathrm{mol} \mathrm{m} \mathrm{m}^{-2} \mathrm{~s}^{-1}\right) ; r=0.46\right)$ suggesting different control mechanisms. The ratio of nitrate reduction to carbon assimilation may be an important mechanism relating plant growth to environment.

\section{ACKNOWLEDGEMENTS}

We thank Keith Plumb for growing the plants, Valerie Mitchell, Janice Turner and Simon Driscoll for excellent technical assistance, Janet Why for preparation of the manuscript and Dr Bill Day for advice on the manuscript. 


\section{LITERATURE CITED}

AmEs, B. N., 1966. Assay of inorganic phosphate, total phosphate and phosphatases. Methods in Enzymology, 8, 115-18.

Arnon, D. I., 1949. Copper enzymes in isolated chloroplasts. Polyphenol oxidases in Beta vulgaris. Plant Physiology, 24, 1-15.

Beevers, L., and Hageman, R. H., 1980. Nitrate and nitrite reduction. In The biochemistry of plants, Volume 5, Amino acids and derivatives. Ed. B. J. Miflin. Academic Press, New York. Pp. 115-68.

BiRd, I. F., CoRnelius, M. J., and KeYs, A. J., 1982. Affinity of RuBP carboxylases for carbon dioxide and inhibition of the enzymes by oxygen. Journal of Experimental Botany, 33, 1004-13.

Brown, J., Small, I. S., and Wray, J. L., 1981. Age-dependent conversion of nitrate reductase to cytochrome c reductase species in barley leaf extracts. Phytochemistry, 20, 389-98.

Buchanan, B. B., Schürman, P., and Kalberer, P. P., 1971. Ferredoxin-activated fructose diphosphatase of spinach chloroplasts. Journal of Biological Chemistry, 2462, 5952-9.

Cossins, E. A., and SiNHA, S. K., 1965. Occurrence and properties of L-amino-acid:2-glyoxylate aminotransferase in plants. Canadian Journal of Biochemistry, 43, 495-506.

Evans, J. R., 1983. Nitrogen and photosynthesis in the flag leaf of wheat (Triticum aestivum L.). Plant Physiology, 72, 297-302.

Friedrich, J. W., and Huffaker, R. C., 1980. Photosynthesis, leaf resistances, and ribulose-1,5bisphosphate carboxylase degradation in senescing barley leaves. Ibid. 65, 1103-7.

HAGEMAN, R. H., 1979. Integration of nitrogen assimilation in relation to yield. In Nitrogen assimilation of plants. Eds E. J. Hewitt and C. V. Cutting. Academic Press, London. Pp. 591-611.

- and REID, A. J., 1980. Nitrate reductase from higher plants. Methods in Enzymology, 69, 270-80.

HELMER HORST, E., and STOKEs, G. B., 1980. Microcentrifuge desalting: a rapid, quantitative method for desalting small amounts of protein. Analytical Biochemistry, 104, 130-5.

Hesketh, J. D., Ogren, W. L., Hageman, M. E., and Peters, D. B., 1981. Correlations among leaf $\mathrm{CO}_{2}$-exchange rates, areas and enzyme activities among soybean cultivars. Photosynthesis Research, 2, 21-30.

HuFfaker, R. C., 1983. Protein metabolism. In Plant physiology, Volume VIII, Nitrogen metabolism. Eds F. C. Steward and R. G. S. Bidwell. Academic Press, Orlando. Pp. 267-333.

KERR, M. W., and Groves, D., 1975. Purification and properties of glycolate oxidase from Pisum sativum leaves. Phytochemistry, 14, 359-62.

Keys, A. J., Bird, I. F., Cornelius, M. J., Lea, P. J., Wallsgrove, R. M., and Miflin, B. J., 1978. Photorespiratory nitrogen cycle. Nature, 275, 741-3.

- Sampaio, E. V. S. B., Cornelius, M. J., and Bird, I. F., 1977. Effect of temperature on photosynthesis and photorespiration of wheat leaves. Journal of Experimental Botany, 28, 525-33.

Lawlor, D. W., Boyle, F. A., Young, A. T., Keys, A. J., and Kendall, A. C., 1987a. Nitrate nutrition and temperature effects on wheat: photosynthesis and photorespiration of leaves. Ibid. 38, 393-408.

Kendall, A. C., and KeYs, A. J., 1987b. Nitrate nutrition and temperature effects on wheat: soluble components of leaves and carbon fluxes to amino acids and sucrose. Ibid. (Submitted.)

LORIMER, G. H., BADGER, M. R., and ANDREWS, T. J., 1977. D-ribulose-1,5-bisphosphate carboxylaseoxygenase. Improved methods for the activation and assay of catalytic activities. Analytical Biochemistry, 78, 66-75.

Lowry, O. H., Rosebrough, N. J., Farr, A. L., and Randall, R. J., 1951. Protein measurement with a folin phenol reagent. Journal of Biological Chemistry, 193, 265-75.

Makino, A., MaE, T., and OHIRA, K., 1984. Effect of nitrogen, phosphorus or potassium on the photosynthetic rate and ribulose-1,5-bisphosphate carboxylase content in rice leaves during expansion. Soil Science and Plant Nutrition, 30, 63-70.

NATR, L., 1975. Influence of mineral nutrition on photosynthesis and use of assimilates. In Photosynthesis and productivity in different environments. Ed. J. P. Cooper. C.U.P., Cambridge. Pp. 537-55.

Nevins, D. J., and LoOmis, R. S., 1970. Nitrogen nutrition and photosynthesis in sugar beet (Beta vulgaris L.). Crop Science, 10, 21-5.

Perchorowicz, J. T., Raynes, D. A., and Jensen, R. G., 1981. Light limitation of photosynthesis and activation of ribulose bisphosphate carboxylase in wheat seedlings. Proceedings of the National Academy of Science, U.S.A., 78, 2985-9. 
REDGEWELL, R. J., 1980. Fractionation of plant extracts using ion-exchange sephadex. Analytical Biochemistry, 107, 44-50.

Schmidt, C. N. G., Cornelius, M. J., Burton, S., Parry, M. A. J., Millard, B. N., Keys, A. J., and Gutteridge, S., 1984. Purified ribulose- $P_{2}$ carboxylase from wheat with high specific activity and with fast activation. Photosynthesis Research, 5, 47-62.

Schmidt, M. R., and EDWARDs, G. E., 1981. Photosynthetic capacity and nitrogen use efficiency of maize, wheat and rice: a comparison between $\mathrm{C}_{3}$ and $\mathrm{C}_{4}$ photosynthesis. Journal of Experimental Botany, 32, 459-66.

SCholl, R. L., Harper, J. E., and Hageman, R. H., 1974. Improvements of the nitrite colour development in assays of nitrate reductase by phenazine methosulphate and zinc acetate. Plant Physiology, 53, 825-8.

Thomas, H., and Stoddart, J. L., 1980. Leaf senescence. Annual Review of Plant Physiology, 31, 83-111.

Thomas, S. M., 1976. In Rothamsted Experimental Station Report. Pp. 35-6.

- 1977. In Rothamsted Experimental Station Report. Pp. 37.

Wallsgrove, R. M., Lea, P. J., and Miflin, B. J., 1979. Distribution of the enzymes of nitrogen assimilation within the pea leaf cell. Plant Physiology, 63, 232-6.

WITTENBACH, V. A., 1979. Ribulose bisphosphate carboxylase and proteolytic activity in wheat leaves from anthesis through senescence. Ibid. 64, 884-7.

- Franceschi, V. R., and GiaquinTa, R. T., 1984. Soybean leaf storage proteins. In Current topics in plant biochemistry and physiology, Volume 3. University of Missouri, Columbia.

Yemm, E. W., and Cocking, E. C., 1955. The determination of amino acids with ninhydrin. The Analyst, 80, 209-14. 